LINGUA, Vol. 14, No. 2, September 2017

p ISSN: 1979 9411; e ISSN: 2442 238X

Http://lingua.pusatbahasa.or.id; Email: presslingua@gmail.com

Center of Language and Culture Studies, Surakarta, Indonesia

Hasugian, Monika Relly. 2017. Upacara Kematian Saur Matua Batak Toba: Analisis Tradisi Lisan. Lingua (2017), 14(2): 225 242.

\title{
UPACARA KEMATIAN SAUR MATUA BATAK TOBA: ANALISIS TRADISI LISAN
}

\author{
Relly Monika Hasugian \\ Pascasarjana Program Fakultas Ilmu Budaya \\ Universitas Sumatera Utara \\ Jl. A. Hakim No1, Kampus USU, Medan 20155
}

Email: icahasugian@gmail.com

\begin{abstract}
This study reports funeral ceremony tradition of Saur Matua of Batak Toba, Indonesia. Oral tradition is the traditional delivered orally using words, transformed by the times and the adjustment to the context of the times. A qualitative using ethnograpic approach is used in this study. Data were explored from an observation and an in-deth interview on the conduct of Saur Matua ceremony. The study revealed that Saur Matua in Toba Batak has 10 full characteristics of oral tradition: (1) Representing the events as the context; (2) Having a cultural activity; (3) To be observed and watched; (4) Traditional characteris; (5) Inherited from generation to generation; (6) Delivering process "from mouth to ear"; (7) Containing the values and cultural norms; (8) Having varies version; (9) Owned jointly by a particular community, and (10) Potentially revitalized and raised as a source of cultural industries. The Saur Matua has a text, co-text, context, value or norm, meaning or function and local wisdom that must be preserved continuously by generations to be not lost from the death tradition in Toba Batak society.
\end{abstract}

Keywords: oral tradition, Toba Batak tribes, Saur Matua, revitalization.

Tradisi lisan adalah kegiatan budaya tradisional suatu komunitas yang diwariskan secara turun temurun dengan media lisan dari suatu generasi ke generasi lain baik tradisi itu berupa susunan kata-kata lisan (verbal) maupun tradisi lain yang bukan lisan (non-verbal)(Sibarani, 2014:47). Dengan pengertian ini, tradisi lisan berbeda dari tradisi kelisanan karena tradisi kelisanan adalah tradisi menggunakan bahasa sebagai alat komunikasi lisan, sedangkan tradisi lisan adalah tradisi kegiatan tradisional yang disampaikan secara lisan seperti kebiasaan menari dan bermain gendang atau yang menggunakan kata-kata lisan seperti kebiasaan mendongeng. Tradisi lisan selalu mengalami transformasi akibat perkembangan zaman dan penyesuaiannya dengan konteks zaman.

Kehidupan sebuah tradisi pada hakikatnya berada pada proses transformasi itu karena sebuah tradisi tidak akan hidup kalau tidak mengalami transformasi. Kemampuan penyesuaian tradisi lisan dengan modernisasi atau konteks zaman merupakan kedinamisan sebuah tradisi. Tradisi lisan masa lalu tidak akan mungkin dapat dihadirkan pada masa kini persis seperti dahulu karena telah mengalami transformasi sedemikian rupa bahkan mungkin telah "mati" karena tidak hidup lagi 
LINGUA, Vol. 14, No. 2, September 2017

p ISSN: 1979 9411; e ISSN: 2442 238X

Http://lingua.pusatbahasa.or.id; Email:presslingua@gmail.com

Center of Language and Culture Studies, Surakarta, Indonesia

Hasugian, Monika Relly. 2017. Upacara Kematian Saur Matua Batak Toba:

Analisis Tradisi Lisan. Lingua (2017), 14(2): 225 242.

pada komunitasnya, tetapi nilai dan normanya dapat diaktualisasikan pada masa sekarang. Tradisi budaya pada zaman dahulu oleh nenek moyang pada umumnya diteruskan melalui kelisanan sedangkan tradisi budaya sekarang ini didominasi oleh keberaksaraan sehingga secara praktis kebudayaan itu diteruskan dalam dua cara, yakni dengan tradisi lisan dan tradisi tulis atau dengan 'kelisanan' dan 'keberaksaraan' (Havelock, 1963).

Ketika kita bicara tentang kelisanan, kita pasti menghubungkannya dengan keberaksaraan sehingga kelisanan pada hakikatnya tidak dapat dipisahkan dari keberaksaraan. Meskipun tidak dapat dipisahkan namun kedua konsep harus dibedakan untuk memahami keduanya sekaligus menjelaskan hubungannya. Tradisi lisan sudah pasti bagian dari tradisi kelisanan tetapi tradisi kelisanan belum tentu tradisi lisan. Sebagaimana diketahui, tradisi lisan tidak selamanya berbentuk unsur verbal seperti bermantra, tetapi harus mengandung pesan verbal tentang tradisi masa lalu. (Vansina 1985:27-28) mengatakan bahwa tradisi lisan merupakan pesan verbal berupa pernyataan dilaporkan dari masa silam kepada generasi masa kini, yang kemungkinan pesan verbal itu dituturkan, dinyanyikan dengan atau tanpa diiringi oleh musik. Wujud tradisi lisan itu dapat berupa:

1) Tradisi berbahasa dan beraksara lokal seperti tradisi menggunakan bahasa etnik atau bahasa daerah dan tradisi menggunakan aksara lokal (aksara Batak, Jawi, Bugis, dll)

2) Tradisi berkusasteraan lisan seperti tradisi menggunakan perumpamaan atau peribahasa rakyat, tradisi penyebutan ungkapan tradisional, tradisi pertanyaan tradisional atau berteka-teki, berpuisi rakyat, bercerita rakyat, melantukan nyanyian rakyat, dan menabalkan gelar kebangsawanan,

3) Tradisi pertunjukan dan permainan rakyat seperti kepercayaan rakyat, teater rakyat, permainan rakyat, tari rakyat, adat-istiadat, upacara atau ritual, dan pesta rakyat,

4) Tradisi upacara adat dan ritual seperti upacara yang berkenaan dengan siklus kehidupam (kelahiran, pernikahan, dan kematian) dan upacara yang berkenaan dengan siklus mata pencaharian (menanam, merawat, dan memanen),

5) Tradisi teknologi tradisional seperti arsitektur rakyat, ukiran rakyat, pembuatan pupuk tradisional, kerajinan tangan rakyat, keterampilan jahitan pakaian, keterampilan perhiasan adat, pengolahan makanan dan minuman rakyat, dan peramuan obat-obat tradisional,

6) Tradisi pelambangan atau simbolisme seperti tradisi gerak isyarat tradisional, bunyi isyarat untuk komunikasi rakyat,

7) Tradisi seni dan musik rakyat seperti tradisi mempertunjukan permainan gendang, seruling dan alat-alat musik lainnya,

8) Tradisi pertanian rakyat seperti bercocok tanam tradisional, perladangan tradisional, dan peternakan tradisional,

9) Tradisi kerajinan tangan seperti pembuatan alat-alat dapur, alat-alat rumah tangga, dan alat-alat untuk perolehan mata pencaharian,

10) Tradisi kuliner atau makanan tradisional seperti pembuatan makanan-makanan khas rakyat, 
11) Tradisi obat-obat atau pengobatan tradisional termasuk pengobatan yang khas lokal,

12) Tradisi panorama dan kondisi alam seperti kebiasaan kegiatan menikmati pemandangan alam dan kondisi alam.

Semua wujud tradisi lisan tersebut mengindikasikan ada kegiatan budaya, yang sekaligus membedakannya dari sastra lisan dan folklor. Istilah tradisi lisan memiliki inti 'tradisi' dan unsur yang menerangkan 'lisan'. Singkatnya tradisi lisan adalah suatu tradisi yang disampaikan secara lisan. Tradisi adalah kebudayaan masa lalu yang memiliki proses keberlanjutan hingga sekarang dan kemungkinan hingga masa mendatang. Proses keberlanjutan itu merupakan rangkaian transmisi budaya yang disampaikan secara lisan. Adapun ciri-ciri tradisi lisan yaitu:

1. Merupakan performansi, kegiatan atau peristiwa sebagai konteks penggunaannya.

2. Memiliki kegiatan budaya, kebiasaan atau kebudayaan berbentuk lisan, sebagian lisan dan bukan lisan.

3. Dapat diamati dan ditonton.

4. Bersifat tradisional.

5. Diwariskan secara turun temurun.

6. Proses penyampaian 'dari mulut ke telinga'.

7. Mengandung nilai-nilai dan norma-norma budaya.

8. Memiliki versi-versi.

9. Milik bersama komunitas tertentu.

10. Berpotensi direvitalisasi dan diangkat sebagai sumber industri budaya.

Ciri-ciri di atas bersifat kumulatif, artinya semua tradisi lisan sekaligus memiliki ciri-ciri itu. Kalau hanya memiliki satu atau dua ciri di atas, kebiasaan itu belum tentu tergolong pada tradisi lisan. Jenis pengetahuan yang dapat digali dari wujud tradisi lisan dapat berupa:

1) Usage (cara-cara), berkaitan dengan cara melakukan sesuatu seperti cara berpantun, cara menari, cara berdongeng dan cara melaksanakan ritual,

2) Folksways (kebiasaan), berkaitan dengan sejumlah kebiasaan yang dilakukan masyarakat seperti kebiasaan menghormati orang yang lebih tua,

3) Mores (norma atau etika), berkaitan dengan sejumlah perbuatan yang diperbolehkan dan yang dilarang dalam kehidupan bermasyarakat,

4) Norms (norma), berkaitan dengan aturan-aturan yang berlaku dalam masyarakat,

5) Custom (adat-istiadat), berkaitan dengan adat yang harus diketahui dan ditaati oleh setiap individu dalam masyarakat,

6) Skill (keterampilan), berkaitan dengan keterampilan melakukan produk tradisional,

7) Competence (kompetensi), berkaitan dengan kemampuan tentang sesuatu terutama yang datangnya dari masa lalu,

8) Aesthetics (keindahan), berkaitan dengan keindahan yang diperoleh dari pemandangan alam dan kondisi alam. 
LINGUA, Vol. 14, No. 2, September 2017

p ISSN: 1979 9411; e ISSN: 2442 238X

Http://lingua.pusatbahasa.or.id; Email:presslingua@gmail.com

Center of Language and Culture Studies, Surakarta, Indonesia

Hasugian, Monika Relly. 2017. Upacara Kematian Saur Matua Batak Toba:

Analisis Tradisi Lisan. Lingua (2017), 14(2): 225 242.

Semua jenis pengetahuan tersebut di atas dapat dikategorikan pada dua fungsi tradisi lisan yakni tradisi lisan yang berfungsi untuk menciptakan kedamaian dan yang berfungsi untuk meningkatkan kesejahteraan. Dengan memperhatikan ciri-ciri, wujud, jenis pengetahuan yang terdapat didalamnya, peran dan fungsinya, tradisi lisan merupakan tradisi budaya yang disampaikan dari satu generasi ke generasi lain secara turun-temurun melalui media lisan. Tradisi budaya menyiratkan kebiasaan masyarakat dalam hubungan tiga dimensi waktu, yakni waktu lampau, waktu sekarang dan waktu mendatang.

Setiap tradisi lisan memiliki bentuk dan isi. Bentuk terbagi atas:

a) Teks, memiliki struktur yang berupa unsur verbal baik verbal baik berupa bahasa yang tersusun ketat seperti bahasa sastra maupun bahas naratif yang akan mengantarkan tradisi lisan nonverbal seperti teks pengantar sebuah performansi. Struktur yang dapat dilihat dari struktur makro, struktur alur, dan struktur mikro;

b) Ko-teks, adalah keseluruhan unsur yang mendampingi teks seperti unsur paralinguistik, prosemik, kinetik dan unsur material lainnya yang terdapat dalam tradisi lisan;

c) Konteks, mensyaratkan bahwa semua tradisi lisan harus memiliki peristiwa tradisi lisan, yang disebut dengan performansi. Konteks merupakan kondisi yang berkenaan dengan budaya, sosial, situasi dan ideologi tradisi lisan.

Pada hakikatnya, semua tradisi lisan memiliki teks, ko-teks, dan konteks dalam performansi. Akan tetapi, teks tradisi lisan yang verbal dan sebagian verbal merupakan unsur internal tradisi lisan seperti dalam tradisi bermantra, sedangkan teks tradisi lisan nonverbal merupakan media kesaksian seperti tradisi permainan rakyat. Isi tradisi lisan berupa nilai atau norma, yang dikristalisasi dari makna, maksud, peran dan fungsi. Nilai atau norma tradisi lisan yang dapat digunakan menata kehidupan sosial itu disebut dengan kearifan lokal. Tingkatan pertama isi adalah makna atau maksud dan fungsi atau peran. Tingkatan kedua adalah nilai atau norma, yang dapat diinferensikan dari makna atau maksud dan fungsi atau peran dengan adanya keyakinan terhadap nilai atau norma itu. Tingkatan ketiga adalah kearifan lokal yang merupakan penggunaan nilai dan norma budaya dalam menata kehidupan sosial secara arif.

\section{METODE}

Dalam Penelitian ini, peneliti menggunakan metode etnografi sebagai metode penelitian. Metode etnografi merupakan salah satu metode penelitian kualitatif, etnografi digunakan untuk meneliti perilaku-perilaku manusia berkaitan dengan perkembangan budaya (Spradley, 1980). Secara harafiah, etnografi berarti tulisan atau laporan tentang suatu suku bangsa yang ditulis oleh seorang antropolog atas hasil penelitian lapangan (field work) selama sekian bulan atau sekian tahun.

Metode penelitian etnografi dianggap mampu menggali informasi secara mendalam dengan sumber-sumber yang luas. Dengan teknik "observatory participant", etnografi menjadi sebuah metode penelitian yang unik karena mengharuskan partisipasi peneliti secara langsung dalam sebuah masyarakat atau komunitas sosial tertentu (Spradley, 1980). Metode etnografi disebut juga metode kualitatif, metode kualitatif 
LINGUA, Vol. 14, No. 2, September 2017

p ISSN: 1979 9411; e ISSN: 2442 238X

Http://lingua.pusatbahasa.or.id; Email:presslingua@gmail.com

Center of Language and Culture Studies, Surakarta, Indonesia

Hasugian, Monika Relly. 2017. Upacara Kematian Saur Matua Batak Toba:

Analisis Tradisi Lisan. Lingua (2017), 14(2): 225 242.

merupakan sebuah paradigma Naturalistic inquiry atau inkuiri alamiah. Sebagai paradigma alamiah, metode kualitatif menggunakan kriteria relevansi. Relevansi ini adalah signifikasi dari pribadi terhadap lingkungan senyatanya. Usaha menemukan kepastian dan keaslian merupakan hal yang penting dalam penelitian ilmiah. Paradigma alamiah ini mencoba menemukan dengan menganalisis data yang diperoleh secara sistematis. Model penelitian alamiah ini mencoba menemukan data empiris dari hasil wawancara dan pengamatan atau observasi di lapangan (Denzin, 2009:2). Penelitian ini dilakukan di kecamatan tarutung desa Sipoholon, Tapanuli Utara, Sumatera Utara. Penduduk di daerah desa Sipoholon, kecamatan Tarutung, Tapanuli Utara.

\section{Data dan Sumber Data}

Data primer adalah berbagai informasi dan keterangan yang diperoleh langsung dari sumbernya, yaitu pihak keluarga, masyarakat setempat, dan tokoh adat yang dijadikan informan penelitian. Jenis data ini meliputi informasi dan keterangan mengenai upacara Kematian Saur Matua Batak Toba. Data sekunder adalah berbagai teori dan informasi yang diperoleh tidak langsung dari sumbernya, selain itu data sekunder juga merupakan data pelengkap dan pembanding. Data sekunder yang dimaksudkan adalah berupa data dalam bentuk laporan, buku, artikel ilmiah, hasil seminar, dan lain-lain. Data-data ini membantu peneliti untuk mengetahui sejarah, falsafah, dan latar belakang tradisi lisan upacara Kematian Saur Matua Batak Toba.

Sumber data dalam penelitian ini dibedakan menjadi dua, yaitu: sumber data lisan dan sumber data tulisan. Sumber data lisan adalah data yang didapatkan melalui observasi langsung dan wawancara dengan informan. Informan yang dimaksud adalah: pihak keluarga, masyarakat setempat, dan tokoh adat. Sumber data tulisan mengacu pada sumber-sumber tertulis upacara Kematian Saur Matua Batak Toba. Sumber data dengan mengunakan kata,verba, dan frasa dalam umpasa yang diucapkan dari sumber informan, parhata atau tokoh adat dalam upacara Kematian Saur Matua Batak Toba.

\section{Teknik Pengumpulan Data}

Dalam penelitian kualitatif, peneliti terlibat langsung dalam proses pengumpulan data. Kedudukan peneliti dalam penelitian kualitatif selain sebagai perencana sekaligus sebagai pelaksana pengumpul data atau sebagai instrument (Moeloeng, 2006). Untuk mengumpulkan data penelitian, peneliti menggunakan teknik observasi partisipasi artinya pengamatan terhadap kegiatan manusia dengan menggunakan pancaindra (Bungin, 2011:118) dalam hal ini peneliti masuk ke desa Sipoholon upacara kematian tempat dilaksanakan upacara Kematian Saur Matua Batak Toba mengadakan pengamatan menggunakan pancaindra, khususnya mata dan telinga. Kemudian peneliti melakukan wawancara mendalam untuk memperoleh keterangan penelitian dengan tanya jawab sambil bertatap muka dengan informan kunci dengan atau tanpa meggunakan pedoman wawancara (Bungin, 2011:111).

\section{Teknik Pengumpulan Data}

Peneliti menggunakan beberapa teknik pengumpuan data untuk mendapatkan data lengkap dan terpercaya, yaitu: 
1. Teknik observasi melalui teknik rekam, catat. Peneliti melakukan perekaman upacara Kematian Saur Matua Batak Toba saat upacara berlangsung. Penyimakan penggunaan bahasa ini diwujudkan dengan teknik rekam dan teknik catat. Ketika menyimak dan merekam, peneliti tidak terlibat dalam komunikasi. Adapun teknik catat dilakukan dengan pencatatan pada kartu data yang segera dilanjutkan dengan klasifikasi atau pengelompokkan. Data dikumpulkan dan disimpan atau dicatat dalam kartu data. Pencatatan dapat dilakukan langsung ketika teknik pertama selesai (teknik simak) dan dengan menggunakan alat tulis tertentu. Komponen-komponen yang mengisi kartu data adalah nomor data, konteks, tuturan, analisis data dan bentuk tindak tutur.

2. Teknik wawancara, yaitu mendapatkan informasi dengan cara bertanya langsung kepada informan, dalam hal ini kepada tokoh-tokoh adat, pendeta, masyarakat setempat, tamu pada upacara Saur Matua. peneliti mengumpulkan data atau informasi dengan cara melakukan tanya jawab dan bertatap muka secara langsung dengan informan sehingga informasi yang diperoleh lebih jelas mengenai tata cara Saur Matua Batak Toba. Wawancara adalah proses memperoleh keterangan untuk tujuan penelitian dengan cara tanya jawab sambil bertatap muka antara si penanya atau pewawancara dengan si penjawab atau informan dengan menggunakan alat yang dinamakan panduan wawancara (Nazir, 1988). Wawancara dilakukan dengan mengajukan pertanyaan langsung kepada informan atau subjek penelitian ini. Fokus pengumpulan data melalui observasi dan wawancara tampak pada Tabel 1.

\section{Tabel 1. Daftar Teknik Pengumpulan Data}

\begin{tabular}{|l|l|l|}
\hline No & Teknik Pengumpulan Data & Rumusan Masalah \\
\hline $\mathbf{1}$ & $\begin{array}{l}\text { 1. } \\
\text { 2. } \text { Wawancara }\end{array}$ & $\begin{array}{l}\text { Bagaimana Tahapan upacara Saur } \\
\text { Matua } \text { Batak Toba? }\end{array}$ \\
\hline $\mathbf{2}$ & $\begin{array}{l}\text { 1. Observasi } \\
\text { 2. }\end{array}$ & $\begin{array}{l}\text { Bagaimana upacara Saur Matua } \\
\text { Batak Toba: Analisi Tradisi Lisan? }\end{array}$ \\
\hline
\end{tabular}

\section{Teknik Analisis Data}

Analisis data merupakan tahap selanjutnya setelah data terkumpul. Data yang sudah siap dan sudah dicatat dalam kartu data dan diklasifikasikan secara sistematis sesuai dengan kepentingan penelitian kemudian dianalisis. Dalam menganalisis data, peneliti menggunakan model interaktif dari Miles and Huberman (1994) dan Saldana (2014). Komponen-komponen analisis data model interaktif ini mencakup:

1. Kondensasi Data (Data Condensation). Pada tahap ini, peneliti melakukan kondensasi data dengan cara: (a) Memilih, (b) Memfokuskan, (c) Menyederhanakan, (d) Mengabstraksi, dan (e) Mentransformasi.

2. Penyajian Data (Data Display). Peneliti membuat daftar awal kode yang sesuai dengan pedoman wawancara dan rekaman. Data berupa rekaman diberi kode dan dikelompokkan dalam beberapa kelompok. 
LINGUA, Vol. 14, No. 2, September 2017

p ISSN: 1979 9411; e ISSN: 2442 238X

Http://lingua.pusatbahasa.or.id; Email:presslingua@gmail.com

Center of Language and Culture Studies, Surakarta, Indonesia

Hasugian, Monika Relly. 2017. Upacara Kematian Saur Matua Batak Toba: Analisis Tradisi Lisan. Lingua (2017), 14(2): 225 242.

3. Penarikan Kesimpulan (Conclusion Drawing). Berdasarkan data yang telah direduksi dan disajikan, peneliti membuat kesimpulan yang didukung dengan bukti yang kuat pada tahap pengumpulan data.

\section{Teknik Penyajian Hasil Analisis Data}

Dalam pemaparan hasil analisis data digunakan metode formal dan informal. Metode formal digunakan untuk memaparkan hasil analisis data yang berupa kaidahkaidah atau lambang-lambang yang digunakan untuk memberi tanda pada kesalahan, anomali, tanda pengucapan, tambahan informasi, dan sebagainya, sedangkan metode informal berupa pemaparan hasil analisis dalam bentuk kata-kata uraian.

\section{HASIL DAN BAHASAN}

\section{Upacara adat kematian dalam tradisi masyarakat Batak}

Dalam tradisi Batak, orang yang mati akan mengalami perlakuan khusus, terangkum dalam sebuah upacara adat kematian. Upacara adat kematian tersebut diklasifikasi berdasar usia dan status si mati. Untuk yang mati ketika masih dalam kandungan (mate di bortian) belum mendapatkan perlakuan adat (langsung dikubur tanpa peti mati). Tetapi bila mati ketika masih bayi (mate poso-poso), mati saat anakanak (mate dakdanak), mati saat remaja (mate bulung), dan mati saat sudah dewasa tapi belum menikah (mate ponggol), keseluruhan kematian tersebut mendapat perlakuan adat : mayatnya ditutupi selembar ulos (kain tenunan khas masyarakat Batak) sebelum dikuburkan. Ulos penutup mayat untukmate poso-poso berasal dari orang tuanya, sedangkan untuk mate dakdanak dan mate bulung, ulos dari tulang (saudara laki-laki ibu) si orang mati. Upacara adat kematian semakin sarat mendapat perlakuan adat apabila orang yang mati:

1. Telah berumah tangga namun belum mempunyai anak (mate di paralangalangan / mate punu)

2. Telah berumah tangga dengan meninggalkan anak-anaknya yang masih keci (mate mangkar)

3. Telah memiliki anak-anak yang sudah dewasa, bahkan sudah ada yang kawin, namun belum bercucu (mate hatungganeon)

4. Telah memiliki cucu, namun masih ada anaknya yang belum menikah (mate sari matua)

5. Telah bercucu tidak harus dari semua anak-anaknya (mate saur matua).

Saurmatua menjadi tingkat tertinggi dari klasifikasi upacara, karena mati saat semua anaknya telah berumah tangga. Memang masih ada tingkat kematian tertinggi diatasnya, yaitu mate saur matua bulung (mati ketika semua anak-anaknya telah berumah tangga, dan telah memberikan tidak hanya cucu, bahkan cicit dari anaknya laki-laki dan dari anaknya perempuan. Namun keduanya dianggap sama sebagai konsep kematian ideal (meninggal dengan tidak memiliki tanggungan anak lagi).

\section{Upacara Saur Matua dikalangan Masyarakat Batak Kristen}


LINGUA, Vol. 14, No. 2, September 2017

p ISSN: 1979 9411; e ISSN: 2442 238X

Http://lingua.pusatbahasa.or.id; Email: presslingua@gmail.com

Center of Language and Culture Studies, Surakarta, Indonesia

Hasugian, Monika Relly. 2017. Upacara Kematian Saur Matua Batak Toba:

Analisis Tradisi Lisan. Lingua (2017), 14(2): 225 242.

Ketika seseorang masyarakat Batak mati saur matua, maka sewajarnya pihakpihak kerabat sesegera mungkin mengadakan musyawarah keluarga (martonggo raja), membahas persiapan pengadaan upacara saur matua. Pihak-pihak kerabat terdiri dari unsur-unsur dalihan natolu. Dalihan natolu adalah sistem hubungan sosial masyarakat Batak, terdiri dari tiga kelompok unsur kekerabatan, yaitu: pihak hula-hula (kelompoks orang keluarga marga pihak istri), pihak dongan tubu (kelompok orang-orang yaitu: teman atau saudara semarga), dan pihak boru (kelompok orang-orang dari pihak marga suami dari masing-masing saudara perempuan kita, keluarga perempuan pihak ayah). Martonggo raja dilaksanakan oleh seluruh pihak di halaman luar rumah duka, pada sore hari sampai selesai. Pihak masyarakat setempat (dongan sahuta) turut hadir sebagai pendengar dalam rapat (biasanya akan turut membantu dalam penyelenggaraan upacara).

Rapat membahas penentuan waktu pelaksanaan upacara, lokasi pemakaman, acara adat sesudah penguburan, dan keperluan teknis upacara dengan pembagian tugas masing-masing. Keperluan teknis menyangkut penyediaan peralatan upacara seperti: pengadaan peti mati, penyewaan alat musik beserta pemain musik, alat-alat makan beserta hidangan buat yang menghadiri upacara, dsb.

\section{Pelaksanaan Upacara Kematian "Saur Matua"}

Pelaksanaan upacara bergantung pada lamanya mayat disemayamkan. Idealnya diadakan ketika seluruh putra-putri orang yang mati saur matua dan pihak hulahula telah hadir. Namun karena telah banyak masyarakat Batak merantau, sering terpaksa berhari-hari menunda pelaksanaan upacara (sebelum dikuburkan), demi menunggu kedatangan anak-anaknya yang telah berdomisili jauh.

Hal seperti itu dalam martonggo raja dapat dijadikan pertimbangan untuk memutuskan kapan pelaksanaan puncak upacara saur matua sebelum dikuburkan. Sambil menunggu kedatangan semua anggota keluarga, dapat dibarengi dengan acara non adat yaitu menerima kedatangan para pelayat (seperti masyarakat non-Batak). Pada hari yang sudah ditentukan, upacara saur matua dilaksanakan pada siang hari, di ruangan terbuka yang cukup luas (idealnya dihalaman rumah duka). Jenazah yang telah dimasukkan kedalam peti mati diletakkan ditengah-tengah seluruh anak dan cucu, dengan posisi peti bagian kaki mengarah ke pintu keluar rumah. Di sebelah kanan peti jenazah adalah anak-anak lelaki dengan para istri dan anaknya masing-masing, dan di sebelah kiri adalah anak-anak perempuan dengan para suami dan anaknya masingmasing. Di sinilah dimulai rangkaian upacara saur matua.

Ketika seluruh pelayat dari kalangan masyarakat adat telah datang (idealnya sebelum jamuan makan siang). Jamuan makan merupakan kesempatan pihak penyelenggara upacara menyediakan hidangan kepada para pelayat berupa nasi dengan lauk berupa hewan kurban (sapi atau babi) yang sebelumnya telah dipersiapkan oleh para parhobas (orang-orang yang ditugaskan memasak segala makanan selama pesta). Setelah jamuan makan, dilakukan ritual pembagian jambar (hak bagian atau hak perolehan dari milik bersama). (Periksa Gambar 1).

Jambar terdiri dari empat jenis berupa: juhut (daging), hepeng (uang), tortor (tari), dan hata (berbicara. Masing-masing pihak dari dalihan natolu mendapatkan 
hak dari jambar sesuai ketentuan adat. Pembagian jambar hepeng tidak wajib, karena pembagian jambar juhut dianggap menggantikan jambar hepeng. Namun bagi keluarga status sosial terpandang, jambar hepeng biasanya ada. Urutan pembagian jambar diawali pembagian jambar juhut. Daging yang dijadikan sebagai jambar juhut adalah kerbau atau kuda. Pemotongan daging juga dilakukan oleh pihak parhobas. Daging yang sudah dipotong, dibagi-bagi dalam keadaan mentah. Secara universal, pembagian jambar juhut itu adalah:

1. Kepala $(u l u)$ untuk raja adat (pada masa sekarang adalah pembawa acara selama upacara),

2. Leher (rungkung atau tanggalan) untuk pihak boru,

3. Paha dan kaki (soit) untuk dongan sabutuha,

4. Punggung dan rusuk (somba-somba) untuk hula-hula,

5. Bagian belakang (ihur-ihur) untuk hasuhuton. Adapun dongan sahuta (teman sekampung), pariban (kakak dan adik istri kita) dan ale-ale (kawan karib), dihitung sama sebagai pihak dongan sabutuha.

Gbr. 1. Bagian-bagian kerbau yang dijadikan sebagai jambar juhut (kiri), jambar hepeng (tengah), sketsa ulos ragi idup sebagai ulos saput (kanan)

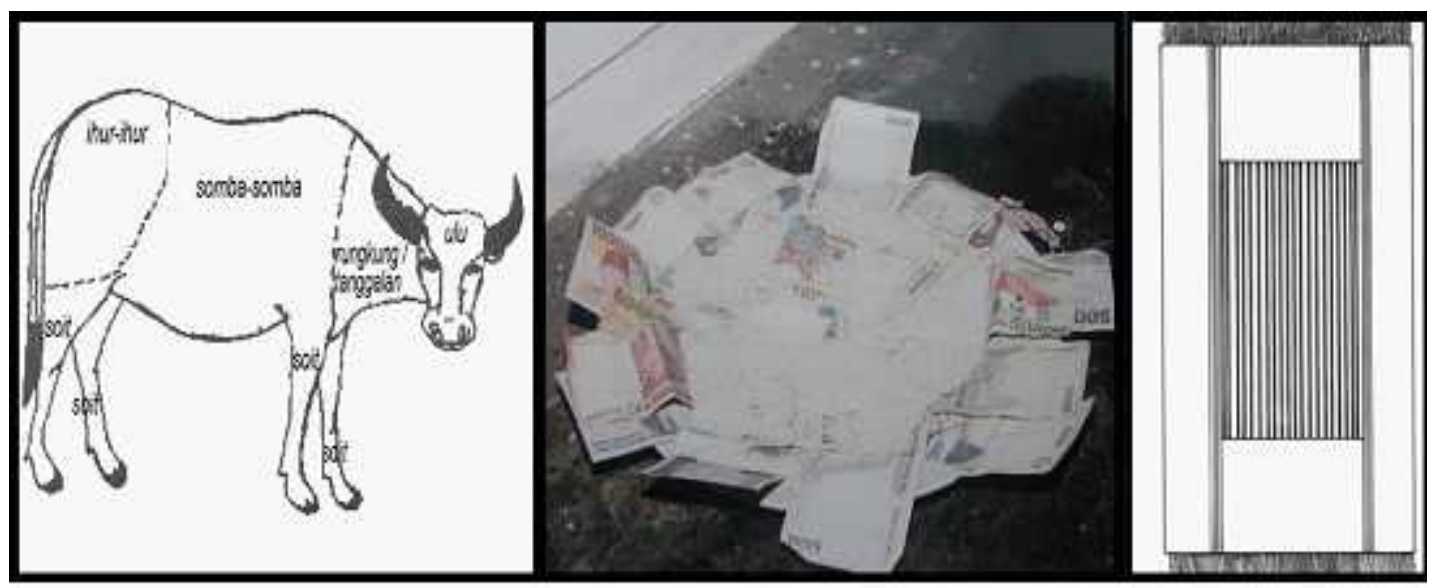

Selepas ritus pembagian jambar juhut, dilanjutkan ritual pelaksanaan jambar hata berupa kesempatan masing-masing pihak memberikan kata penghiburan kepada anak-anak orang yang mati saur matua (pihak hasuhuton). Urutan kata dimulai dari hula-hula, dilanjutkan dengan dongan sahuta, kemudian boru/bere, dan terakhir dongan sabutuha. Setiap pergantian kata penghiburan, diselingi ritual jambar tor-tor, yaitu ritus manortor (menarikan tarian tor-tor). Tor-tor adalah tarian tradisional khas Batak. Tarian tor-tor biasanya diiringi musik dari gondang sabangunan (alat musik tradisional khas Batak). Gondang sabangunan adalah orkes musik tradisional Batak, terdiri dari seperangkat instrumen yakni : 4 ogung, 1 hesek, 5 taganing, 1 odap, 1 gondang, 1 sarune. Adapun urutan gondang dalam upacara saurmatua seperti terangkum dalam Gambar 2. 
Pada masa terkini, semakin tidak jelas apa yang diwajibkan sebagai perlengkapan yang harus disediakan dalam upacarasaur matua. Sedangkan pada tahun 1980an, bila yang meninggal saur matua harus lengkap "marsanggul marata" (sijagaron) yang ditaruh dalam ampang (bakul) terdiri dari:

1. Boni sitamba tua (menandakan sudah banyak turunan).

2. Miak-miak (kemiri yang menunjukkan semangat dari nenek moyang),

3. Gantang (menandakan sudah bercicit)

4. Baringin (menandakan punya anak perempuan dan cucu)

5. Pira ni manuk (telur ayam yang menandakan hidup baik)

6. Sanggar (menandakan segala pencaharian almarhum selama ini diperoleh dengan cara baik-baik)

7. Ampang menandakan bahwa yang meninggal adalah saur matua, ampang diletakkan didekat kepala almarhum

8. Suhut (pihak keluarga yang kemalangan memberikan adat penghormatan berupa makanan yang terdiri dari : tandok (sumpit) berisi kemiri 3 buah, telor satu buah, sirih lengkap dan uang dalam jumlah bilangan genap kepada pargonsi, diterima olehparsarune (peniup sarune) sebagai pimpinan rombongan. Kemiri melambangkan semangat roh nenek moyang, telor melambangkan kesatuan dan hidup baik, uang dan sirih.

\begin{tabular}{|c|c|c|}
\hline $\mathrm{NO}$ & \begin{tabular}{|c|} 
nama gondang \\
(berurutan)
\end{tabular} & keterangan \\
\hline 1 & Gondang Ni Pargonsi & 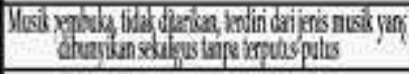 \\
\hline 2 & Goniang Ni Haskhton & 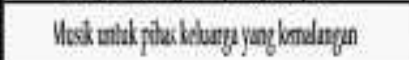 \\
\hline 3 & $\begin{array}{l}\text { Gordang NiDmgan } \\
\text { Salfutulat }\end{array}$ & 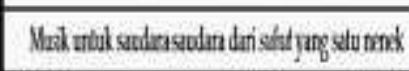 \\
\hline 4 & Gondang Ni Paronuar & 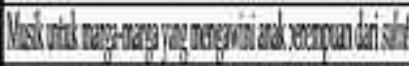 \\
\hline$j$ & Gendang NiAlz-Ale & 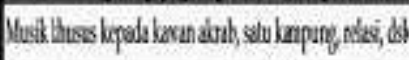 \\
\hline 6 & Gondong Hula.Hula & 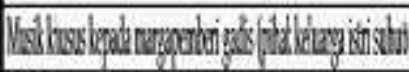 \\
\hline 7 & Goudang Purtiobus & 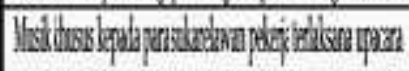 \\
\hline 8 & Gomdang Harnipor & 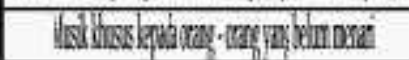 \\
\hline
\end{tabular}

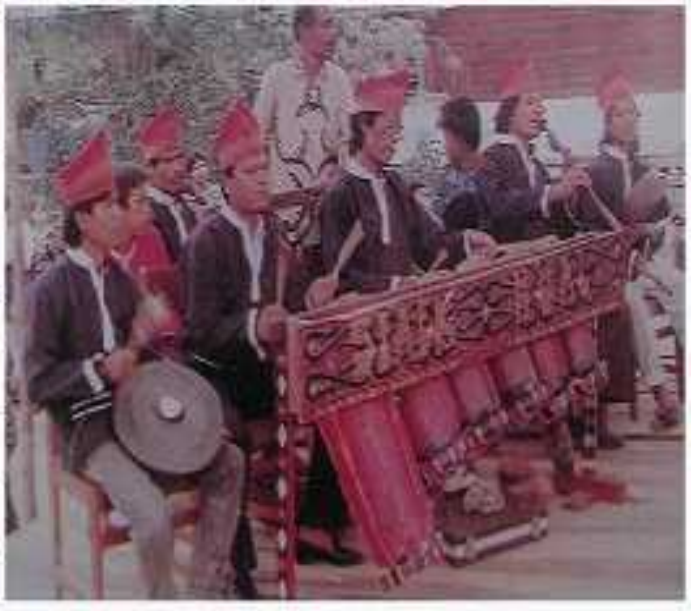

\section{Gbr.2 Daftar urutan musik gondang yang dimainkan dalam upacara saur matua (kiri), pemain musik gondang sabangunan (kanan)}

Kini masyarakat Batak Kristen memahami upacara saur matua bukan untuk menyembah si orang tua agar kekuatan sahala diberikan kepada anak-cucunya, tetapi sebagai ungkapan syukur kepada Tuhan atas anugerah umur panjang kepada orang yang mati saur matua. Sedangkan konsep religi mati saur matua sebagai "kematian ideal" tetap dipertahankan, karena orientasi sosial budaya masa kini juga menganggap mati di usia yang sangat tua adalah kematian yang paling baik. Selain itu, motivasi pengadaan 
LINGUA, Vol. 14, No. 2, September 2017

p ISSN: 1979 9411; e ISSN: 2442 238X

Http://lingua.pusatbahasa.or.id; Email: presslingua@gmail.com

Center of Language and Culture Studies, Surakarta, Indonesia

Hasugian, Monika Relly. 2017. Upacara Kematian Saur Matua Batak Toba:

Analisis Tradisi Lisan. Lingua (2017), 14(2): 225 242.

upacara saur matua pada masa kini diarahkan sebagai pendewasaan rohani secara adat maupun agama baru mereka (Kristen). Hal itu terwujud karena dalam upacara saur matua, masyarakat Batak dapat berkumpul dengan seluruh keluarga besar.

Gagasan pendewasaan rohani tersebut mereka dapatkan setelah merefleksikan upacara saur matua menjadi sebuah bentuk ucapan syukur dari seluruh anak-cucu orang yang mati kepada Tuhan, bukan lagi kepada arwah leluhur. Ada juga masyarakat Batak Kristen yang tidak setuju terkait kewajiban pelaksanaan upacara saur matua, karena kurang masuk akal dan tidak jelas tujuannya. Upacara saur matua sebagai "kematian ideal" menjadi kurang tepat dengan pemahaman iman Kristiani kalau didominasi oleh keinginan "pamer". Apalagi sering terjadi, keluarga sudah "habis-habisan" membiayai perawatan orang tuanya dari mulai sakit-sakitan hingga meninggal, tapi masih harus "habis-habisan" membiayai upacara saur matua demi memenuhi tuntutan adat. Seharusnya adat tidak harus dijadikan beban.

Pada masa terkini, berkembang pula pemikiran teologis dari denominasi Kristen yang berbeda dari HKBP, menyatakan upacara saur matua penting untuk dilestarikan. Orang yang mati harus segera dikuburkan, dan menunggu berhari-hari, apalagi manortor di depan peti terbuka berisi jenazah yang sudah sembab dan berair. Hal ini dapat merusak kesehatan meskipun jenazah telah disuntik formalin untuk memperlambat terjadinya pembusukan mayat.

Pada kesempatan manortor pihak tulang (saudara laki-laki ibu almarhum), menyelimutkan ulos ragi idup langsung ke badan mayat. Selain itu bona tulang (hulahula dari pihak marga saudara laki-laki nenek almarhum) dan bona ni ari (hulahula dari pihak marga ibu kakek almarhum) juga memberikan ulos (biasanya ulos sibolang). Ulos dikembangkan di atas peti mayat, sebagai tanda kasih sayang yang terakhir. Kemudian pihak hula-hula secara khusus mangulosi (menyematkan ulos) kepada pihak boru dan hela (menantu) sebagai simbol pasu-pasu (berkat) yang diucapkannya.

Pihak hula-hula memberikan ulos sibolang sebagai ulos sampetua kepada istri atau suami yang ditinggalkan, dengan meletakkan di atas bahu. Apabila orang yang mati telah lebih dahulu ditinggalkan istri atau suaminya, tentunya ulos tidak perlu lagi diberikan). Kemudian hula-hula memberikan ulos panggabei kepada semua keturunan, dengan menyampirkan ulos (sesaat secara bergantian) di bahu masing-masing anak lakilaki yang tertua sampai yang paling bungsu (terakhir diberikan kembali ke anak lelaki tertua di sertai kata-kata berkat). Sama halnya yang dilakukan oleh pihak hula-hula, pihak tulang dari setiap hasuhuton juga melakukan ritus tersebut.

Kemudian masing-masing wanita dari rombongan tulang manortor sambil menjunjung boras sipiritondi (beras tepung tawar yang bermakna pemberian berkat dan memperkuat tondi), untuk kemudian diserahkan kepada pihak hasuhuton. Sedangkan rombongan undangan lainnya (dongan sabutuha, boru, bere, pariban, teman-teman dari pihak hasuhuton) secara bergilir diundang untuk manortor (lihat pada tabel). Namun mereka tidak melakukan ritus pemberian pasu-pasu. Setelah jambar tor-tor dari semua pelayat selesai, selanjutnya adalah kata-kata ungkapan sebagai balasan pihak hasuhuton kepada masing-masing pihak yang memberikan jambar hata dan jambar tortor tadi. Selanjutnya, salah seorang suhut mengucapkan jambar hata balasan 
(mangampu) sekaligus mengucapkan terima kasih kepada semua pihak yang telah membantu terlaksananya upacara. Setiap peralihan mangampu dari satu pihak ke pihak lain, diselingi ritus manortor.

Manortor dilakukan dengan sambil menghampiri dari tiap pihak yang telah menghadiri upacara tersebut, sebagai tanda penghormatan sekaligus meminta doa restu. Setelah semua ritus tersebut selesai dilaksanakan, upacara adat diakhiri dengan menyerahkan ritual terakhir (acara penguburan berupa ibadah singkat) kepada pihak gereja. Ibadah bisa dilakukan di tempat itu juga, atau ketika jenazah sampai di lokasi perkuburan. Hal ini menyesuaikan kondisi, namun prinsipnya sama saja. Maka sebelum peti dimasukkan kedalam lobang tanah (yang sudah digali sebelumnya), ibadah singkat dipimpin oleh pihak gereja. Dapat dimulai dari nyanyian rohani pembuka, kotbah, nyanyian rohani penutup, dan doa penutup dari pihak gereja.

Kemudian jenazah yang sudah di dalam peti yang tertutup dikuburkan. Sepulang dari pekuburan, dilakukan ritual adat ungkap hombung. Adat ungkap hombung adalah ritus memberikan sebagian harta yang ditinggalkan si mendiang (berbagi harta warisan) untuk diberikan kepada pihak hula-hula. Namun mengenai adat ungkap hombung ini, telah memiliki variasi pengertian pada masa kini. Idealnya tanpa diingatkan oleh pihak hula-hula, ungkap hombung dapat dibicarakan atau beberapa hari sesudahnya. Apapun yang akan diberikan untuk ungkap hombung, keluarga yang kematian orang tua yang tergolong saur matua hendaklah membawa rasa senang pada pihak hula-hula. Periksa Gambar 3.

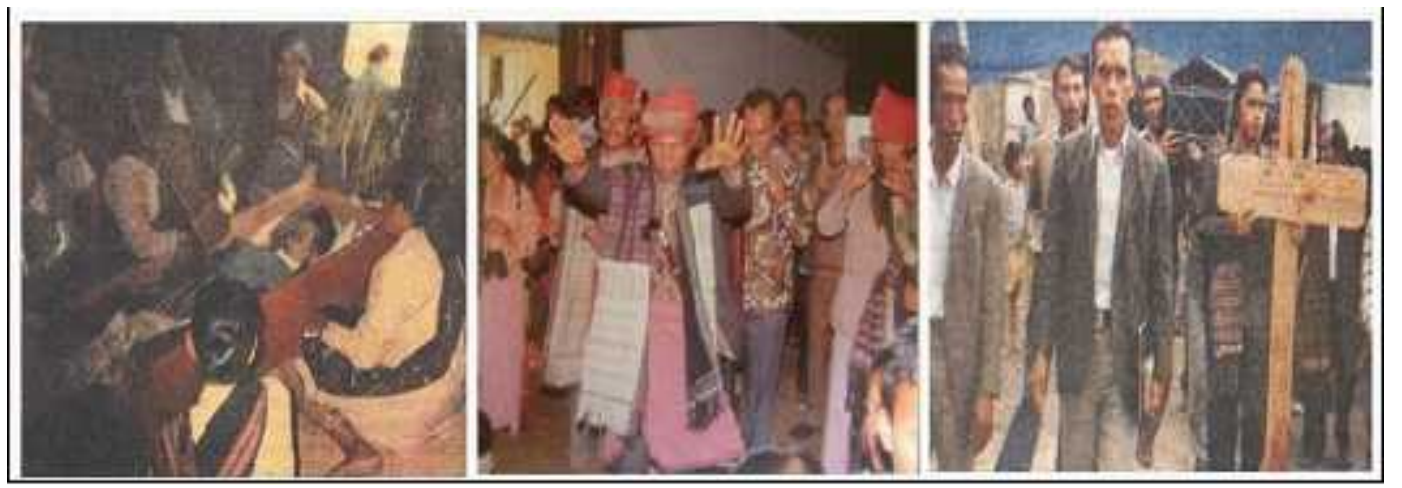

Gbr.3 Jenazah didalam peti dikelilingi oleh para keturunannya (kiri), salah satu gerak tor-tor ( tengah), prosesi penguburan diserahkan kepada pihak gereja (kanan)

\section{Ciri Tradisi Lisan}

Seperti yang sudah disebutkan di bab pendahuluan ada yang namanya ciri tradisi lisan. Berkaitan dengan ciri tersebut maka upacara kematian saurmatua batak toba akan diteliti apakah sesuai dengan ciri-ciri tradisi lisan.

1) Merupakan performansi, kegiatan atau peristiwa sebagai konteks penggunaannya. Ciri ini sangat penting untuk membedakan tradisi lisan dari sastra lisan, folklor lisan, dan folklor sebagian lisan. Tradisi lisan harus memiliki peristiwa tertentu dan oleh karenanya pemahaman terhadap tradisi lisan itu harus dikaitkan atau 
LINGUA, Vol. 14, No. 2, September 2017

p ISSN: 1979 9411; e ISSN: 2442 238X

Http://lingua.pusatbahasa.or.id; Email: presslingua@gmail.com

Center of Language and Culture Studies, Surakarta, Indonesia

Hasugian, Monika Relly. 2017. Upacara Kematian Saur Matua Batak Toba:

Analisis Tradisi Lisan. Lingua (2017), 14(2): 225 242.

tergantung pada konteks peristiwa tersebut. Oleh karena terikat pada konteks peristiwa maka tradisi lisan memiliki tempat kejadian dan situasi kejadian. Upacara kematian saurmatua batak toba memiliki ciri ini karena dilakukan pada suatu upacara adat yaitu upacara perkawinan dan sudah ditentukan waktu, tempat dan situasi bagaimana tradisi tersebut dilakukan. Tradisi ini biasanya dilakukan 1 minggu atau 7 hari setelah kematian, bertempat di rumah keluarga anak laki-laki atau anak perempuan dan situasi yang diciptakan adalah suasana adat iistiadat terakhir bersama yang orang meningggal dipersembahkan orang/ keluarga yang ditinggalkan.

2) Memiliki kegiatan budaya, kebiasaan atau kebudayaan berbentuk lisan, sebagian lisan, dan bukan lisan. Dalam hal ini, baik ada maupun tidak ada kelisanan dalam wujud kebiasaan itu atau baik ada maupun tidak ada unsur-unsur verbal dalam wujud kegiatan budaya itu. Upacara kematian saurmatua pada batak toba dapat digolongkan pada tradisi lisan karena adanya kebiasaan atau kegiatan budaya pada saat dilakukan dan hal ini dapat diturunkan dengan media lisan seperti pada saat orangtua atau kerabat memberi nasehat-nasehat, dan pada saat si anak menyampaikan ungkapan kesedihannya/kebahagiannya. Dimana hal ini belum tentu tertulis pada zaman dahulu namun dapat disampaikan secara lisan secara turun temurun.

3) Dapat diamati dan ditonton. Tradisi lisan harus dapat dipertunjukkan atau dipertontonkan atau dilihat orang dalam suatu konteks peristiwa tertentu. Ciri ini menyiratkan bahwa tradisi lisan memiliki pelaku dan penonton yang mempertunjukkann tradisi lisan itu. Pada upacara kematian saurmatua pada batak toba ciri di atas dapat dilihat langsung karena tradisi yang dilakukan memang wajib memiliki pelaku dan penonton dimana pelaku utama adalah keluarga, anak perempuan, anak laki-laki, cucu, cicit, bahkan buyut. Serta semua keluarga dan para dalian na tolu sedangkan para penontonnya adalah para dalian na tolu itu sendiri dan para kerabat-kerabat lainnya.

4) Bersifat tradisional. Ciri ini menyiratkan bahwa tradisi lisan harus mengandung unsur warisan etnik, baik murni bersifat etnis maupun kreasi baru yang ada unsur etnisnya. Tradisi upacara kematian saurmatua pada batak toba ini memang sudah mengalami perkembangan zaman dimana terkadang waktu dilakukannya bisa dilakukan setelah terjadi akad nikah dan melibatkan kedua pengantin namun unsur etnisnya tidak hilang dilihat dari adat istiadat yang dilakukan untuk yang meninggal tetap sama dari zaman dulu maupun zaman sekarang karena adat istiadat yang dilakukan itu yang sangat penting dan dipahami oleh semua keluarga.

5) Diwariskan secara turun-temurun. Tradisi lisan itu diwariskan dari satu generasi ke generasi lain. Ada anggapan bahwa minimal tiga pewarisan generasi dengan alasan bahwa pewarisan tiga generasi itu mencerminkan pewarisan yang terpantau dari kakek/nenek ke ayah/ibu ke anak-anak. Tradisi upacara kematian saurmatua ada suku batak toba ini juga merupakan pewarisan dari kakek ke ayah lalu ke anakanak dan dapat dilihat ada tiga generasi di dalamnya.

6) Proses penyampaian "dari mulut ke telinga". Ciri ini yang menjadikan kebiasaan atau budaya bukan lisan tergolong tradisi lisan karena budaya bukan lisan itu, 
LINGUA, Vol. 14, No. 2, September 2017

p ISSN: 1979 9411; e ISSN: 2442 238X

Http://lingua.pusatbahasa.or.id; Email:presslingua@gmail.com

Center of Language and Culture Studies, Surakarta, Indonesia

Hasugian, Monika Relly. 2017. Upacara Kematian Saur Matua Batak Toba:

Analisis Tradisi Lisan. Lingua (2017), 14(2): 225 242.

seperti adat istiadat, disampaikan dari mulut melalui berbicara sampai ke telinga anak-anaknya melalui mendengar. Penyampaian melalui berbicara (mulut) dan mendengar (telinga) dalam kajian ilmu bahasa disebut dengan penyampaian lisan. Dengan demikian tradisi yang disampaikan, diajarkan, disosialisasikan dan diwariskan secara lisan disebut tradisi lisan. Pada upacara kematian saurmatua pada suku batak toba pertama sekali dilakukan pada generasi pertama tidak ada bukti bagaimana tradisi itu dilakukan hanya disampaikan dari mulut oleh si pembicara dan sampai ke telinga si pendengar. Bagaimana tradisi itu dilakukan, apa-apa saja yang terjadi pada saat tradisi juga direkam dengan mendengar dan melihat dan disampaikan kepada generasi selanjutnya sehingga tetap terus bisa ada sampai sekarang.

7) Mengandung nilai-nilai dan norma-norma budaya. Para leluhur mewariskan didikan yang baik (nilai) dan aturan yang benar (norma) kepada keturunannya, yang bermanfaat dalam menata kehidupan generasi penerusnya. Nilai yang terkandung pada upacara kematian saurmatua pada suku batak adalah dari nasehat-nasehat yang disampaikan pada dalian na tolu tentang bagaimana keluarga harus bisa bersikap baik, sopan santun dan ramah serta menyayangi keluarga barunya nanti sebagaimana dia diasuh di keluarganya selama ini. Karena nilai-nilai kehidupan yang sudah diajarkan orangtuanya kepadanya dari dia lahir sampai besar dan akan menikah pastilah nilai-nilai yang baik, jadi si anak harus bisa menjaga dan mengamalkan nilai-nilai tersebut dengan baik juga. Begitu juga dengan normanorma yang diterapkan padanya dari lahir hingga dewasa adalah norma-norma yang sarat akan kebaikan, dan bermartabat tinggi yang diharapkan nantinya dapat dia terapkan kembali kepada anak-anaknya kelak.

8) Memiliki versi-versi. Sebagai tradisi yang disampaikan secara lisan, sebuah tradisi lisan berpotensi memiliki bentuk-bentuk yang berbeda yang disebut dengan varian atau versi. Pada tradisi upacra kematian saurmatua pada suku batak pun bisa memiliki ciri tersebut, dimana pada generasi dahulu yang mengikuti acara hanya keluarga inti dan keluarga dekat saja, namun sekarang sudah bisa dihadiri oleh kerabat-kerabat dekat dan dahlian na tolu.

9) Milik bersama komunitas tertentu. Karena sifatnya yang lisan dan anonim, tradisi lisan merupakan miliki semjua masyarakat secara kolektif. Semua anggota masyarakat dalam suatu komunitas mereka memiliki tradisi lisan itu sehingga setiap orang berhak atas tradisi lisan itu. Begitupun pada tradisi upacara kematian saurmatua pada suku batak ini juga merupakan milik komunitas Batak Toba dan setiap orang yang termasuk pada komunitas tersebut berhak untuk melakukannya. Apalagi sekarang komunitas-komunitas masing-masing etnis juga sudah banyak bermunculan, seperti pada komunitas keluarga saya ada namanya "kumpulan keluarga" dan ini muncul karena orang-orang yang memiliki etnis yang sama dengan marga yang sama/serumpun dan berasal dari kampung yang sama.

10) Berpotensi direvitalisasi dan diangkat sebagai sumber industri budaya. Dalam hal ini tradisi upacara kematian saurmatua pada suku Batak Toba sangat berpotensi direvitalisasi dan diangkat sebagai sumber industri budaya karena dari tradisi ini bisa didokumentasikan dan disebarkan apa manfaat dari tradisi ini bagi generasi 
LINGUA, Vol. 14, No. 2, September 2017

p ISSN: 1979 9411; e ISSN: 2442 238X

Http://lingua.pusatbahasa.or.id; Email: presslingua@gmail.com

Center of Language and Culture Studies, Surakarta, Indonesia

Hasugian, Monika Relly. 2017. Upacara Kematian Saur Matua Batak Toba:

Analisis Tradisi Lisan. Lingua (2017), 14(2): 225 242.

muda sekarang yang sudah sangat melupakan nilai-nilai dan norma-norma dari budaya negaranya sendiri. Dan ini berpotensi dalam hal kehidupan sosial rakyat yang sangat kebarat-baratan pada saat ini.

\section{Bentuk dan Isi Tradisi Lisan Saur Matua}

Seperti yang disampakan pada bab sebelumnya selain ciri, setiap tradisi lisan memiliki bentuk dan isi. Sebagai sebuah tradisi lisan, upacara kematian saurmatua pada suku Batak Toba juga memiliki bentuk dan isi.

\section{1) Bentuk tradisi Upacara Kematian Saur Matua}

Bentuk dalam hal ini terbagi atas teks, ko-teks dan konteks. Pada tradisi ini teks bisa dilihat dari nasehat-nasehat yang disampaikan oleh para dalihan na tolu pada saat acara berlangsung. Nasehat-nasehat yang disampaikan merupakan unsur verbal yang baik dengan bahasa-bahasa yang tersusun rapi seperti bahasa sastra. Ko-teks dari tradisi ini direalisasikan dalam bentuk sajian makanan yang diletakkan di atas tampi yang akan dimakan oleh seluruh keluarga. Yang terdapat di dalam tampi itu mewakilkan apa yang ingin diberikan orangtua kepada anak perempuan sebagai makanan terakhir sebelum menikah. Sedangkan konteks merupakan kondisi yang berkenaan dengan budaya, sosial, situasi dan ideologi tradisi lisan. Jika dilihat dari konteks budaya maka tradisi upacara kematian SaurMatua terkait dengan kehidupan dalam hal ini Kematian. Konteks situasi juga terdapat didalamnya karena ada tempat, waktu, cara dan suasana dari tradisi tersebut. Pada hakekatnya semua tradisi lisan memiliki teks, ko-teks dan konteks dalam suatu performansi. Akan tetapi, teks tradisi lisan yang verbal, dan sebagian verbal merupakan unsur internal tradisi lisan seperti dalam tradisi bermantra, sedangkan teks tradisi lisan nonverbal merupakan media kesaksian, penyampaian atau transmisi tradisi lisan itu seperti tradisi permainan rakyat.

2) Isi tradisi lisan upacara Kematian Saur Matua

Terkait isi sebuah tradisi lisan harus berupa nilai atau norma, yang dikristalisasi dari makna, maksud, peran dan fungsi. Tingkatan pertama dari isi adalah makna atau maksud dan fungsi atau peran. Pada Upacara Kematian SaurMatua maknanya adalah dilakukan dengan maksud untuk mengungkapkan rasa kesedihan, sayang dan bahagia orangtua kepada anaknya yang telah meninggal dan tidak akan tinggal bersama mereka lagi dan akan ditinggalkan dan dipisahkan oleh kematian. Hal ini dilakukan agar adat istiadat yang dilakukan kepada yang meninggal dapat terlaksana dengan baik. Tingkatan kedua adalah nilai atau norma, kedua hal tersebut sangat penting dimiliki sebuah tradisi lisan.

Pada tradisi lisan Upacara Kematian SaurMatua juga mengandung nilai-nilai dan norma. Seperti yang diketahui sebuah nilai adalah sesuatu hal baik yang memberikan dampak positif kepada lingkungannnya atas keberadaan tradisi tersebut. Nilai yang terdapat didalamnya diharapkan mewariskan hal-hal positif kepada generasi berikutnya. Ketika tradisi tersebut dilaksanakan maka nilai-nilai tersebut akan dengan sendirinya tersampaikan kepada orang-orang yang hadir. Dalam mangalehen mangan nilai yang disampaikan adalah bagaimana seorang anak bisa mengerti bahwa ketika dia 
LINGUA, Vol. 14, No. 2, September 2017

p ISSN: 1979 9411; e ISSN: 2442 238X

Http://lingua.pusatbahasa.or.id; Email:presslingua@gmail.com

Center of Language and Culture Studies, Surakarta, Indonesia

Hasugian, Monika Relly. 2017. Upacara Kematian Saur Matua Batak Toba:

Analisis Tradisi Lisan. Lingua (2017), 14(2): 225 242.

dibesarkan banyak yang sudah dilakukan dan dikorbankan oleh orangtuanya sehingga dia menjadi besar dan bisa membanggakan orangtuanya.

Tidak ada balas budi yang diharapkan orangtua dari yang sudah diberikan kepada anak-anaknya selain kebahagiaannya melihat anaknya tumbuh besar dan berhasil dalam menjalankan hidupnya hingga si anak menikah. Sehingga nilai-nilai yang diajarkannya seperti patuh pada orangtua, sopan santun dalam bertutur sapa, ramah, memiliki rasa sosial dan tenggang rasa yang tinggi kepada orang lain. Nilai-nilai agama yang diajarkan misalkan rajin beribadah, mengamalkan apa-apa yang terdapat dalam kitab sucinya. Begitu pula dengan norma, yang mengatur bagaimana hidup secara individu ataupun dalam bermasyarakat. Norma-norma ini nantinya akan melahirkan nilai-nilai baik bagi kehidupan.

Dalam kaitannya dengan tradisi lisan upacara kematian SaurMatua ada normanorma yang mengatur. Hal ini dilihat dari makanan yang diberikan mengandung makna, nilai dan norma. Norma pada tradisi ini diajarkan bagaimana harus bertingkah laku seperti yang diajarkan orangtua sehingga anak tersebut tahu seperti apa yang namanya sopan santun, tata krama, dan lain-lain dan hal ini dilambangkan dari makanan yang disajikan anak-anak kepada para kerabat dan keluarga yang ditinggalkan. Tingkatan ketiga adalah kearifan lokal yang merupakan penggunaan nilai dan norma budaya dalam menata kehidupan secara arif Upacara Kematian SaurMatua ini pada akhirnya akan memberikan makna positif kepada sang anak untuk menata kehidupannya lebih baik lagi dalam menjalankan adat istiadat. Hal ini tentunya akan terus bisa dikembangkan kepada anak-anaknya sebagai warisan dari orangtuanya dan tentu saja tidak akan bisa digantikan oleh apapun. Tradisi ini dilakukan dengan harapan sang anak tidak akan melupakan kerja keras orangtua dalam membesarkannya dan akan terus menjaga sopan santun dan tata krama yang diajarkan orangtua kepadanya.

\section{SIMPULAN}

Penelitian ini bertujuan mendeskripsikan proses upacara kematian Saur Matua dalam tradisi masyarakat Batak Toba. Temuan utama penelitian ini menegaskan bahwa tradisi lisan merupakan warisan adat istiadat yang lahir secara turun temurun dan disampaikan dari mulut ke telinga baik tradisi yang berupa lisan (verbal) ataupun yang bukan lisan (non verbal). Tradisi upacara kematian saur matua pada suku Batak Toba memiliki 10 ciri tradisi lisan secara lengkap, yaitu: (1) Merupakan performansi, kegiatan atau peristiwa sebagai konteks penggunaannya; (2) Memiliki kegiatan budaya; (3) Dapat diamati dan ditonton; (4) Bersifat tradisional; (5) Diwariskan secara turuntemurun; (6) Proses penyampaian "dari mulut ke telinga"; (7) Mengandung nilai-nilai dan norma-norma budaya; (8) Memiliki versi-versi; (9) Milik bersama komunitas tertentu, dan (10) Berpotensi direvitalisasi dan diangkat sebagai sumber industri budaya.

Bentuk tradisi upacara kematian saur matua pada suku Batak Toba juga memiliki teks, ko-teks dan konteks, dan juga secara isi tradisi ini memiliki nilai atau norma, makna atau fungsi dan juga mengandung kearifan lokal yang harus terus dilestarikan secara terus menerus dari generasi ke generasi agar tidak hilang dari adat istiadat kematian pada masyrakat batak toba. Upacara saur matua merupakan warisan kebudayaan religi masyarakat batak sejak masa megaltik pra-Kristen. Orang yang 
mati saur matua adalah sebuah "kebanggaan tersendiri" dalam pencapaian keinginan terakhir hidup manusia sebagai mahluk individu maupun sebagai mahluk sosial. Upacara ini diyakini telah beberapa kali mengalami transformasi sejalan dengan perubahan yang terjadi pada kebutuhan dan problematika kehidupan dari waktu ke waktu.

Upacara saur matua hendaknya tetap dilestarikan terkait dengan konsep "kematian ideal", dilakukan dengan tidak membebani secara berlebihan perekonomian anak-anaknya, dan dalam ungkapan syukur kepada Tuhan atas berkat umur yang panjang, hingga saat ajal menjemputnya, masih sempat melihat seluruh anak-anaknya telah berkelurga (bahkan telah memiliki cucu). Namun, upacara ini sulit dilakukan apabila masyarakat Batak Kristen tidak merasakan pengalaman yang menyenangkan dan bermanfat dari upacara tersebut. Perlu ditumbuhkan sikap kritis, peka, dan arif agar upacara kematian saur matua terus mengalami transformasi menuju arah yang lebih baik, agar dapat diterima oleh seluruh lapisan masyarakat Batak (bahkan tidak hanya bagi yang beragama Kristen).

\section{DAFTAR PUSTAKA}

Bungin, Burhan. 2011. Analisis Data Penelitian Kualitatif. Jakarta. Penerbit PT. Raja Grafindo

Denzin. 2009. N. K dan Lincoln, Y. Handbook of Qualitative Research: 591-632. Diterjemahkan oleh Dariyatno. Terbitan ke-1. Yogyakarta: Pustaka Pelajar

M. nazir. 1998. metode penelitian. Jakarta. Ghalia Indonesia

Miles, Metthew B, A. Michael Huberman and Johnny Saldana. 2014. Qualitative Data Analysis, A Methods Sourcebook, Third Edition. Sage Publications, Inc.

Moleong, Lexy. J. 2006. Metode Penelitian Kualitatif. Bandung : PT. Remaja Rosdakarya

Spradley James P. 1980. Participan Observation. New York: Holt.

Tampubolon, Flansius. 2010. Umpasa Masyarakat Batak Toba Dalam rapat Adat: Suatu Kajian Antropolinguistik. Tesis pada Program Pasca Sarjana. USU

Tumanggor, Esto. 2011. Ragam bahasa dalam Upacara Adat Perkawinan Masyarakat Pakpak. Tesis pada Program Pasca Sarjana. USU

Sibarani, Robert 2014 Kearifan Lokal, Hakikat, Peran, dan Metode Tradisi Lisan. Jakarta: Asosiasi Tradisi Lisan.

Situmorang, Hamzon 2013 Minzoku Gaku (Ethnologi) Jepang. Medan: UsuPress.

Takkari, Muhammad 2013 Makalah Kesenian di Sumatera Utara, Beberapa Pemikiran Mengenai Arah dan Pengembangan Fungsinya. Medan.

https://margasiregar.wordpress.com/budaya/

http://gondang.blogspot.co.id/2014_08_25_archive.html 
LINGUA, Vol. 14, No. 2, September 2017

p ISSN: 1979 9411; e ISSN: 2442 238X

Http://lingua.pusatbahasa.or.id; Email:presslingua@gmail.com

Center of Language and Culture Studies, Surakarta, Indonesia

Hasugian, Monika Relly. 2017. Upacara Kematian Saur Matua Batak Toba: Analisis Tradisi Lisan. Lingua (2017), 14(2): 225 242. 